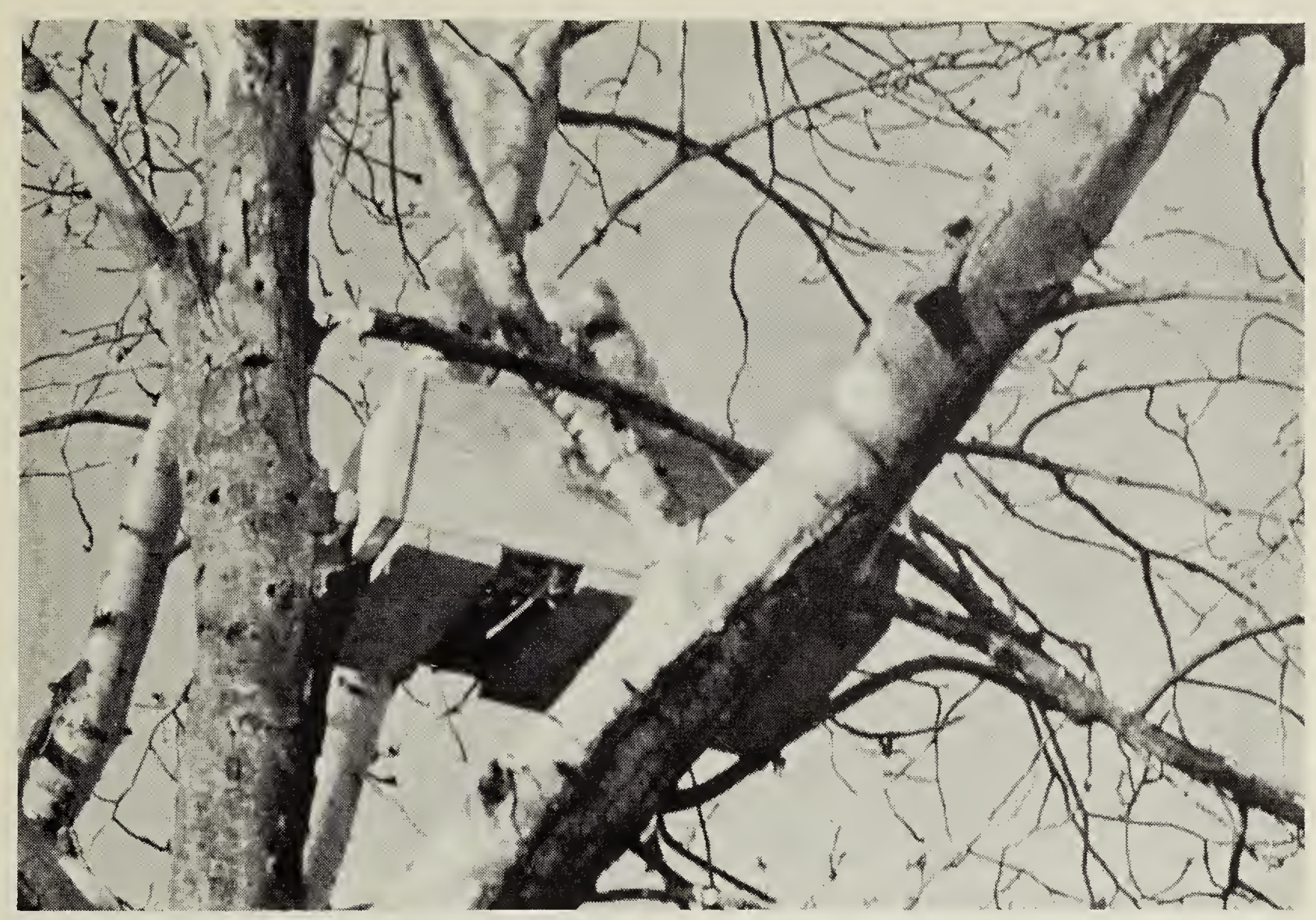

Great Horned Owl nest box

Photo by Dr. C. S. Houston

The record of this nest is submitted because it is unusually complete, and documents well the Horned Owl's amazing capacity for insulation and heat production - by which it is able to keep its eggs as much as 125 Fahrenheit degrees warmer than the environment.

\section{LITERATURE CITED}

Houston, C. Stuart. 1949. The Birds of the Yorkton District, Saskatchewan. Can. FieldNaturalist, $63: 215-41$.

Houston, C. Stuart, and Maurice G. Street. 1959. The Birds of the Saskatchewan River. Saskatchewan Natural History Society, Spec. Pub. No. 2.

Richardson, John, and William Swainson. 1831 (Feb. 1832). Fauna Boreali-Americana, Vol. 2, The Birds. John Murray, London.

\title{
BLACK-THROATED GRAY WARBLERS ON VANCOUVER ISLAND
}

by G. A. Poynter, Victoria, B.C.

The interesting article by $\mathrm{Mr} . \mathrm{F} . \mathrm{H}$. Brazier on Black-throated Gray Warblers in Saskatchewan published in the September, 1965 Blue Jay quoted the A.O.U. Check-list as to the distribution of the species.

Some one, apparently many years ago, indicated that this beautiful warbler did not reach Vancouver Island and any reference since (including the A.O.U. Check-list) has pointed this out. However, at least 15 ardent birders in this area have identified the Black-throated Gray Warbler.

While it is considered infrequent in the Victoria, B.C., area, it is positively an annual fall migrant, passing through this area usually in association with Audubon Warblers during the months of August and September. At least eight individuals were reported during the 1959 migration. Three spring migration records have been noted: May 19, 1946, May 14, 1962, and May 12, 1963, and one summer record of June 19, 1961. 